\title{
Climate Responsive Innovation within the Agricultural Curriculum and Learning System
}

Wilma van Staden, Rhodes University, South Africa

\begin{abstract}
The purpose of this paper is to outline the climate responsive innovation process within the agricultural innovation system of the North West Province, South Africa. The focus was on the embedded curriculum and learning activity system and its responses to social-ecological and earth system changes influenced by climate change. It outlines the barriers and processes hampering curriculum and learning innovations towards climate-smart responsiveness, and also examines the processes required to initiate micro and macro innovations. This paper focusses on how actors within the system can initiate curriculum innovation and climate responsiveness through micro innovations when supported and how this can lead to macro innovations. The system experienced various barriers during the innovation process and overcame many challenges during the journey towards climate-smart responsiveness through the identification of contradictions within the system, developing tools to assist in the transitioning process and expansion in the social-spatial dimension by establishing a learning network within the surrounding communities. The research indicated that the catalysing of the curriculum and learning system required specific tools, time and the understanding of the importance of micro-level innovation.
\end{abstract}

Keywords: curriculum innovation; climate-smart agriculture; agricultural training institutes

\section{Introduction}

This paper explores the types of innovation and significant innovation processes associated with development of the seemingly abstract 'climate-smart agriculture' concept into a concrete curriculum-incorporated approach. This paper is part of a study that emerged during a time when the agricultural training institutes of the North West Province, South Africa, were striving towards new solutions in response to climate change and inclusion of climate-smart agriculture within the agricultural strategic plan of the province. The North West Department of Rural, Environmental and Agricultural Development (READ) stated in its 2014/2015 Annual Report that climate-smart agricultural systems need to be promoted within the province (READ, 2015, p. 82). This was to be undertaken through curriculum innovation and alignment of the teaching and learning practices within the wider Agricultural Innovation System (see Figure 1). However, the approach was not fully conceptualised. Related 
discussions and strategic plans were in place but only at a provincial level, while no clear plan for educational integration was yet established. The Department of Agriculture (DoA, 2008, p. 16) recommended that the agricultural training institutes develop specialist knowledge relevant to local farming practices. What is not included in these recommendations is what support should be provided to the training institutes for cross-cutting issues such as climate change responsiveness including the climate-smart agriculture approach, and how they manifest in the areas of specialisation in the training institutes (DoA, 2005a, p. 5; Department of Agriculuture and Fisheries (DAF), 2008, pp. 107-116; Department of Agriculture, Forestry and Fisheries (DAFF) 2010, pp. 31-35).

Taung Agricultural College (TAC) realised that the agricultural system had evolved new training needs shifting towards climate-smart agriculture (Serage, 2015). This responsive approach was then identified by the College as a means to address agricultural problems such as climate change adaptation, water scarcity, poverty and food insecurity, within the curriculum. However, the process was only in the concept phase and the implementation process was unclear. The concern for change and alignment was an opportunity for formative intervention research to support the training institute's staff during the curriculum and learning innovation process.

At the beginning of this study, 2015, there was little evidence of any formal integration of climate-smart agriculture into the agricultural training institutes' curricula (DAF, 2008, pp. 107-116; Potchefstroom College of Agriculture (PCA), 2009, pp. 5-29; DAFF, 2010, pp.17-19; TAC, 2014a, pp.10-54). However, some of the recommended climate-smart responsive topics were included as part of a subject or as an informal practical component within the national diploma. climate-smart agriculture topics recommended for integration into the agriculture curricula included climate change, principles of climate-smart agriculture, rural health creation, food security, sustainable agricultural practices, renewable energy and energy management, agro-forestry, soil and water management, sustainable irrigation systems, sustainable crop and livestock production, and rain water harvesting and conservation practices (DAF, 2008, pp. 107-116; DAFF, 2010, pp. 31-35; Food and Agriculture Organisation (FAO), 2013, pp. 27).

This paper will show that curriculum innovation towards climate responsiveness is a specialised process. It requires specialist research support while taking into consideration the agricultural innovation system and how the system is structured. This study was initiated as a doctoral thesis, but the research continued thereafter and formed part of the Amanzi [Water] for Food Project (WRC Project No. K5/2271) supported by the Environmental Learning Research Centre (ELRC) of Rhodes University and the Water Research Commission. The project implements a course-activated social learning network approach, which focusses on knowledge dissemination of sustainable water use and food security within the agricultural learning system (Lotz-Sisitka et al., 2016, p. 1).

Initiating innovation within a stable system, in theory, should be relatively easy. However, studies have shown that often innovation is not a straightforward process (Chakeredza et al., 2009; DAFF, 2010; Agbedahin, 2016; Engeström, 2016). This paper outlines how Taung Agricultural College worked with challenges during their journey towards climate-smart 
responsiveness through the identification of contradictions within the system, developing tools to assist in the transitioning process and expansion into the social-spatial dimension by establishing a learning network within the surrounding communities.

\section{Theoretical framework}

A theoretical framework founded on systems thinking was developed to support the research on systems innovation and the process of implementing climate responsive policies to initiate climate-smart innovations in the curriculum and learning practices. An innovation system is structured by the actors involved in the process of innovation. The behaviours, practices and values of these actors are shaped through their engagements and actions within the system's socio-economic environment (Spielman, Ekboir \& Davis, 2009). An innovation system is defined by the generating of new knowledge, interactive learning and the sharing of knowledge. Innovation and learning have always been part of agricultural practices. An Agricultural Innovation Systems framework was developed to facilitate these processes, joining various sub-systems within the agricultural sector as actors participating in the larger organisational learning processes (Spielman et al., 2009). This framework focusses on behaviours and practices that influence institutional innovation (Sumberg, 2005).

By means of this framework, the innovation process was perceived as the outcome of collaboration between actors, or agents, within the agricultural system. Actors exchange information and learning processes as part of engaging with climate-smart agricultural knowledge. Through the Innovation Systems framework, the iterative research process could support and track the innovation process and the emerging complexities of systems innovation.

Cultural Historical Activity Theory (CHAT) elaborates the application of system thinking approach and it was applied to support the research into curriculum and learning innovation. The theoretical framework enabled the research participants to review the context, identify matters of concern and contradictions and to initiate change before examining how their initiatives were developing an expansive learning and innovation process within the system. Cultural Historical Activity Theory is based on Vygotsky's theory of learning and development (Vygotsky, 1978, p. 40) which the researcher drew on to understand knowledge building and innovation developing around contradictions. This provided a perspective for examining and discussing opposing ideas to find a solution while studying the relationships between cause and effect within the system (Engeström, 1987, pp. 188-201).

The first generation of Cultural Historical Activity Theory is based on Vygotsky's concept of mediated action as the unit of analysis and focused on individual or singular activity systems (Zinchenkon, 1985 cited in Engeström, 2016). This study focused on the third generation activity system approach that is centred on social transformation. It incorporates the system structure within a wider range of system interactions analysis, considering the conflicting nature of social practice. Through Engeström's approach, the researcher and participants could identify the complexities, tensions and contradictions outlined through mirror data within the system, but also between their activity system and other activity systems located within the 
wider agricultural innovation system in which they were embedded (see Figure 1; Engeström, 1999, pp. 25, 30).

Margaret Archer's morphogenic social theory (Archer, 1995) provided a valuable lens through which to study innovation from a transformative change perspective. The theory orientated the study to the central problems and challenges surrounding curriculum alignment within the provincial system and the integration of climate-smart agriculture. Sayer (2000, p. 11) noted that the morphogenic framework is a good complementary framework to support social theories such as Cultural Historical Activity Theory. Both theories make an important contribution to the understanding of relationships between the individual and the system. Through the complementary theoretical approach, the study could isolate and identify the activity system work while also analysing the agency-led change. Thus, the theoretical approach enabled the researcher and participants to explore the key research question:

How can college staff involved in the offering of the National Diploma in Agriculture engage through formative intervention to explore practical options for curriculum innovation utilising climate-smart agriculture as a mediating tool?

\section{Methodology}

Between 2015 and 2019 a total of 27 staff members from Taung Agricultural College participated in this study. If participating staff members relocated, the newly appointed staff joined the study. A case-study research design (Yin, 2003) was adopted as this allowed for in-depth investigation, identification and exploration of the initial, transitioning and existing curriculum situations, while uncovering contradictions and possible expansions towards a climate-smart responsive curriculum. The research design also allowed for the determination of the transformation challenges within the agriculture curriculum and learning innovation process.

The project was initiated when the Director of READ, Mr Serage at that time, approached the researcher during an Amanzi [water] for Food related interview about providing support during the curriculum innovation process towards climate change integration within the agricultural training institutes, also known as colleges in South Africa (Serage, 2015). The researcher started working with college staff to compile a contextual profile. Through a systems approach, the contextual profile reflected a clear picture of the complexity of the North West Province agricultural innovation system (see Figure 1). The research participants interviewed identified the need for institutional realignment and curriculum innovation due to the recent changes within the system.

The identified need for alignment and innovation led to the decision to invite all the lecturers and those involved in management of the agricultural training institutes' curriculum and learning practices within the North West Province to a meeting to discuss climate change challenges and curriculum innovation solutions. The preliminary consultative workshop was conducted at Potchefstroom College and 26 lecturers and representatives of the management team from Potchefstroom College of Agriculture and Taung Agricultural College attended. 
The aim of the workshop was to orientate participants to the central problems and challenges surrounding the curriculum alignment with the provincial policies and the possible integration of climate-smart practices within the curriculum.

Through questions and discussion, the participants brought their own experiences into the conversation and collaboratively reviewed, analysed and developed a picture of each college's specific National Diploma curriculum. Together, participants explored how the curriculum was operating and considered what needed to be changed and updated. This allowed them to become aware of problematic aspects and challenges associated with moving towards a climatesmart informed and responsive curriculum, as well as to consider curriculum and learning innovations. A three-day curriculum innovation workshop was held at Rhodes University as part of the Amanzi for Food programme and representatives of both colleges attended, thereby initiating the formative intervention process.

Formative intervention research took the form of tracking and iterative innovation support at Taung Agricultural College. It consisted of intervention-innovation workshops with expansive learning cycles of reflexive innovation. The workshops took a format adapted from the expansive learning process. Each workshop initiated the questioning phase of the expansive learning cycle with participants working with mirror data to question, examine and identify problems within their systemic practices. Participants continued to discuss progress and during each intervention-innovation workshop, they questioned and analysed the system, surfaced contradictions within the system, and mediated an intervention plan towards developing a responsive climate-smart system. Tools developed to assist the innovation process included rainwater harvesting and conservation techniques as a practical component of climate-smart agriculture and curriculum review tools to track the integration of climatesmart agriculture into the curriculum and specific subjects (van Staden, O’Donoghue \& LotzSisitka, 2018, p. 4). Through the formative intervention process (from 2016 to the beginning of 2018), an understanding of the challenges hampering innovation and identification of the innovative processes that led to change during a time of institutional flux were identified.

The feedback process including the identification of the challenges and limitations towards a climate responsive curriculum allowed the agricultural training institute to reflect and build successfully on their progress during 2018 and 2019. An Amanzi for Food workshop held in October 2018 was attended by 22 students and lecturers and many enrolled in a training (level NQF 6) course to access research material on rainwater harvesting and conservation information through Rhodes University and community project networks were built during this time.

\section{Results}

The review and tracking of the supportive innovation process enabled the research participants to shape a picture of the complexities of systems innovation and challenges of the transitioning process to a Climate-Smart responsive system. The Cultural Historical Activity Theory approach allowed the research and research participants to map out the Agricultural Training Institute as a curriculum and learning activity system undergoing Climate-Smart 
curriculum innovation. The curriculum and learning activity system, Figure 2, is embedded in the Agricultural Innovation System of the North West Province. Figure 1 illustrates the Agricultural Innovation System of the North West Province indicating the system drivers, stakeholders and the sub-systems. The system drivers and responses affect the functioning of the curriculum and learning system. In this context, Chakeredza, Temu, Yaye, Mukingwa and Saka (2009) argued that the educational system is the foundation of society's responsive knowledge, competencies and the future ability to cope with social and environmental challenges. The curriculum and learning system, as seen in this study, play a key role in responding to the complex web of issues surrounding climate change responsiveness.

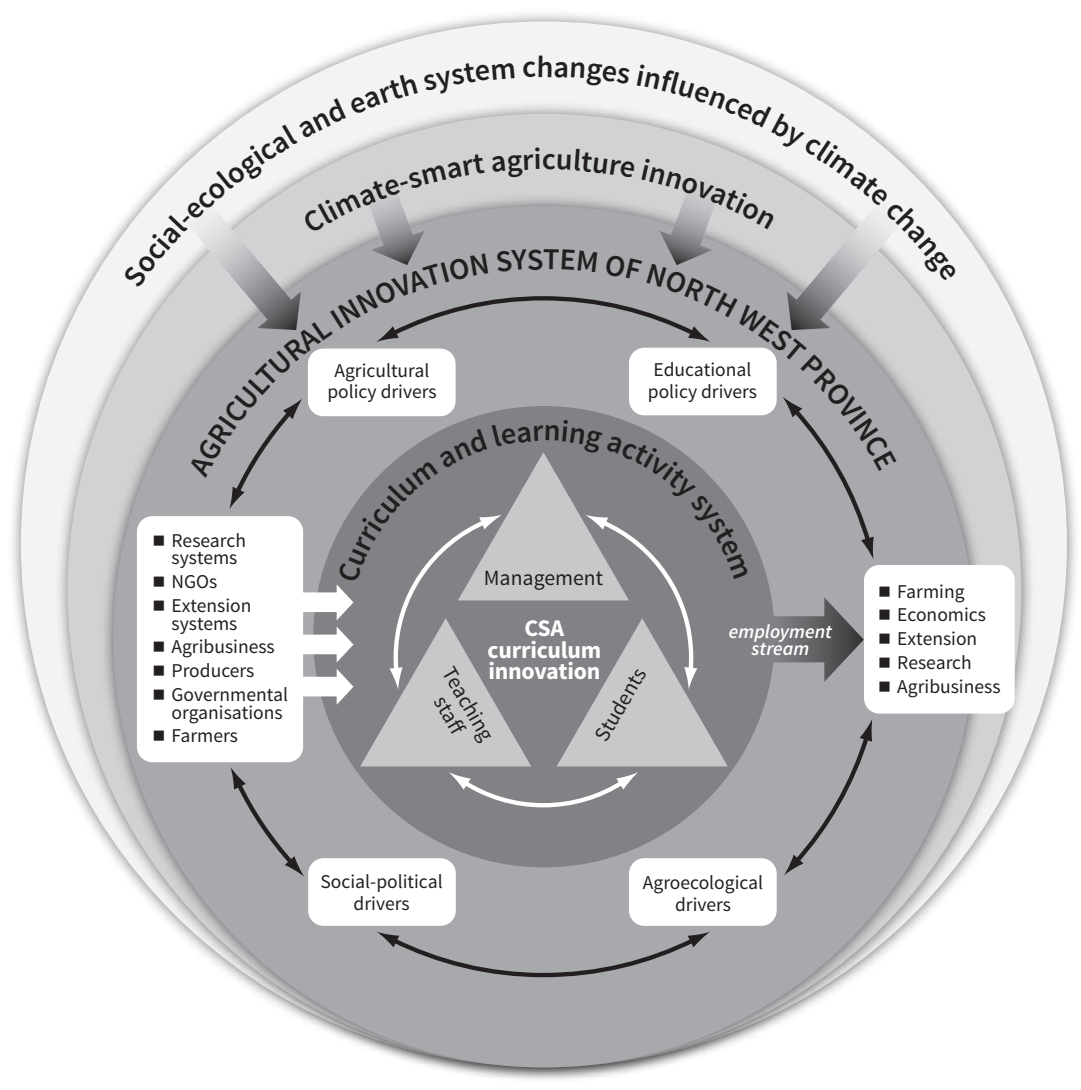

Figure 1 The Agricultural Innovation System of the North West Province, South Africa (adapted for this study from Aerni, Nichterlein, Rudgard \& Sannino, 2015, p. 834) 
Figure 2 represents the curriculum and learning activity system embedded within the Agriculture Innovation System without details of history, culture, contradictions or boundary crossings based on second generation Cultural-Historical Activity System as the primary unit of analysis. A clear picture of the system was developed with the help of the research participants during the study to assist with its analysis.

\section{Instruments:}

Infrastructure and facilities. Prospectus. Curriculum content. Practical and learning sites. CSA concepts. Curriculum Innovation Tool. Hartswater Irrigation scheme.

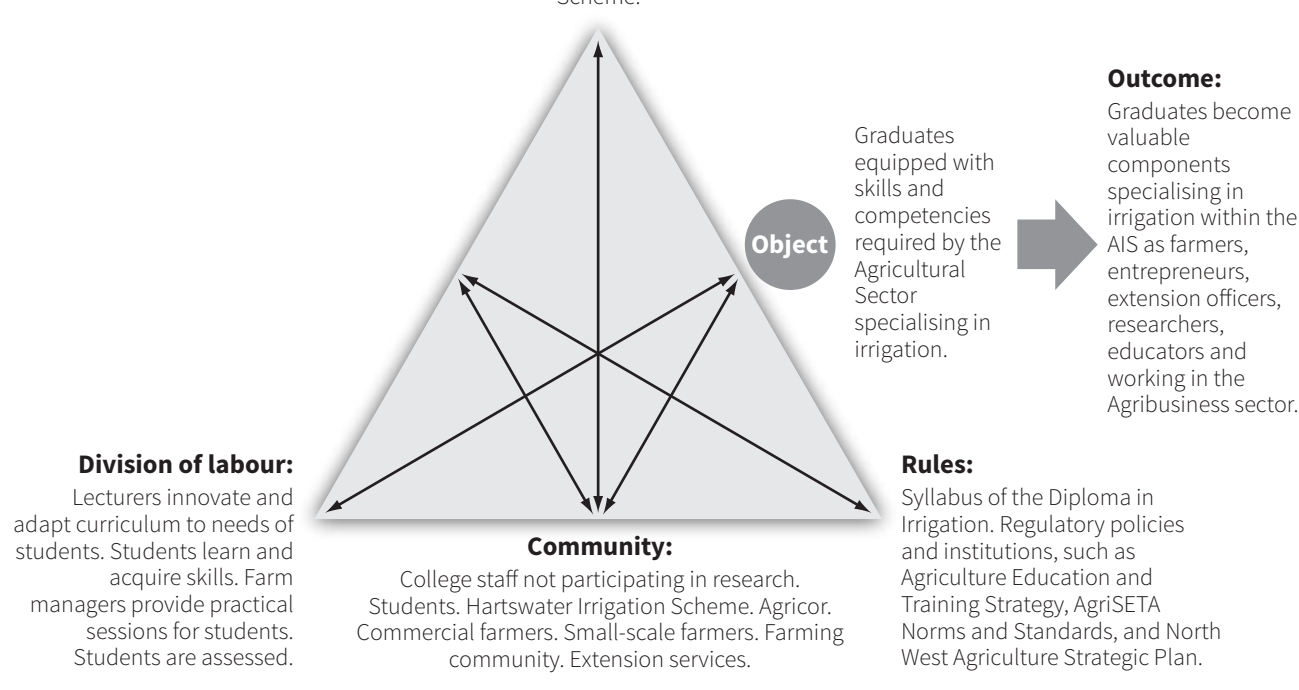

Figure 2 Taung Agricultural College Curriculum and learning activity system seen as part of the North West Agricultural Innovation System depicted in Figure 1

During the study, reflexive tools were developed that aided lecturers and management in reviewing the Climate-Smart responsiveness of their curriculum (Van Staden, O'Donoghue, Lotz-Sisitka, 2018, pp. 7-9). Rainwater harvesting and conservation practices were utilised as a practical component of climate-smart agriculture and a way to implement this concept (Lotz-Sisitka et al., 2016, pp. 69-72). These tools were also utilised to analyse the relationship between transformative learning and transformative agency. Thus, the tool was not only used to support the expansive learning cycles, but also to track innovation and emergence of transformative agency. Through this analysis, the research participants could surface and examine the tensions and contradictions within the system. This in turn enabled the innovation process. These contradictions are listed in Table 1 with the associated drivers of innovation, absences, modelled outcomes, tools developed to assist in the innovation process and the innovations themselves. The micro innovations are based on individual innovations, macro innovations that are institutional and network-based innovations. 
Table 1 Key findings: Iterative curriculum innovation

\begin{tabular}{|c|c|c|c|c|c|c|}
\hline $\begin{array}{l}\text { Curriculum } \\
\text { and } \\
\text { learning } \\
\text { system } \\
\text { drivers } \\
\text { (Figure 1) }\end{array}$ & $\begin{array}{l}\text { Shift or } \\
\text { change in } \\
\text { driver }\end{array}$ & Contradiction & $\begin{array}{l}\text { Revised } \\
\text { outcome } \\
\text { (new } \\
\text { solution) }\end{array}$ & $\begin{array}{l}\text { Tools } \\
\text { developed } \\
\text { and used in } \\
\text { innovation } \\
\text { process }\end{array}$ & $\begin{array}{l}\text { Micro } \\
\text { processes of } \\
\text { innovations } \\
\text { by } \\
\text { individuals }\end{array}$ & $\begin{array}{l}\text { Macro } \\
\text { processes of } \\
\text { innovations } \\
\text { by the group, } \\
\text { network or } \\
\text { institution }\end{array}$ \\
\hline $\begin{array}{l}\text { Agricultural } \\
\text { policy driver } \\
\text { Agro- } \\
\text { ecological } \\
\text { driver }\end{array}$ & $\begin{array}{l}\text { Climate-smart } \\
\text { agriculture } \\
\text { adapted at } \\
\text { policy level as } \\
\text { a responsive } \\
\text { approach } \\
\text { to climate } \\
\text { change } \\
\text { challenges }\end{array}$ & $\begin{array}{l}\text { Climate-smart } \\
\text { agriculture as } \\
\text { an abstract } \\
\text { concept versus } \\
\text { climate-smart } \\
\text { agriculture } \\
\text { as a climate } \\
\text { responsive } \\
\text { curriculum } \\
\text { process }\end{array}$ & $\begin{array}{l}\text { Develop } \\
\text { climate } \\
\text { responsive } \\
\text { curriculum } \\
\text { and learning } \\
\text { practices. } \\
\text { Develop } \\
\text { lecturers' } \\
\text { climate } \\
\text { responsive } \\
\text { knowledge } \\
\text { and practical } \\
\text { competences }\end{array}$ & $\begin{array}{l}\text { - Climate- } \\
\text { smart } \\
\text { innovation } \\
\text { tool - } \\
\text { curriculum } \\
\text { review tool } \\
\text { - Online } \\
\text { climate- } \\
\text { smart } \\
\text { innovation } \\
\text { tools } \\
\text { - Applying } \\
\text { RWH\&C as } \\
\text { a practical } \\
\text { component } \\
\text { of climate- } \\
\text { smart } \\
\text { responsive- } \\
\text { ness }\end{array}$ & $\begin{array}{l}\text { Lecturers } \\
\text { utilised the } \\
\text { curriculum } \\
\text { review tool } \\
\text { for self- } \\
\text { evaluation of } \\
\text { climate-smart } \\
\text { responsive- } \\
\text { ness. } \\
\text { Incorporate } \\
\text { RWH\&C } \\
\text { practices } \\
\text { in practical } \\
\text { student } \\
\text { assignment }\end{array}$ & $\begin{array}{l}\text { Lecturers } \\
\text { completed } \\
\text { a Amanzi for } \\
\text { Food course } \\
\text { (Level NQF 6) } \\
\text { using RWH\&C } \\
\text { material. } \\
\text { Lecturers } \\
\text { graduating in } \\
2019\end{array}$ \\
\hline $\begin{array}{l}\text { Social- } \\
\text { political } \\
\text { drivers }\end{array}$ & $\begin{array}{l}\text { National } \\
\text { diploma, } \\
\text { student } \\
\text { purpose } \\
\text { and career } \\
\text { needs are not } \\
\text { aligned }\end{array}$ & $\begin{array}{l}\text { Student } \\
\text { aspirations } \\
\text { and purpose } \\
\text { of the } \\
\text { programme } \\
\text { and lecturers' } \\
\text { development } \\
\text { of the } \\
\text { programme }\end{array}$ & $\begin{array}{l}\text { Incorporate } \\
\text { climate-smart } \\
\text { topics such as } \\
\text { food security, } \\
\text { homestead } \\
\text { gardening, } \\
\text { small-scale } \\
\text { farming, } \\
\text { entrepreneur- } \\
\text { ship, gender } \\
\text { equity and } \\
\text { poverty } \\
\text { eradication }\end{array}$ & $\begin{array}{l}\text { RWH\&C } \\
\text { practices } \\
\text { included } \\
\text { in teaching } \\
\text { programme. } \\
\text { Teaching } \\
\text { garden } \\
\text { development } \\
\text { of network to } \\
\text { ensure needs } \\
\text { of sector are } \\
\text { always clear } \\
\text { and up to } \\
\text { date. }\end{array}$ & $\begin{array}{l}\text { Starting } \\
\text { community- } \\
\text { based projects } \\
\text { with students }\end{array}$ & $\begin{array}{l}\text { Students } \\
\text { were invited } \\
\text { to attend } \\
\text { the RWH\&C } \\
\text { workshop } \\
\text { and students } \\
\text { completed } \\
\text { a Amanzi for } \\
\text { Food course } \\
\text { (Level NQF 6) }\end{array}$ \\
\hline $\begin{array}{l}\text { Agriculture } \\
\text { and } \\
\text { educational } \\
\text { policy driver } \\
\text { Agro- } \\
\text { ecological } \\
\text { drivers }\end{array}$ & $\begin{array}{l}\text { College } \\
\text { practices } \\
\text { and policies } \\
\text { need to } \\
\text { reflect climate } \\
\text { responsive } \\
\text { and environ- } \\
\text { mentally } \\
\text { friendly } \\
\text { approaches }\end{array}$ & $\begin{array}{l}\text { College } \\
\text { management } \\
\text { practices } \\
\text { versus the } \\
\text { practical } \\
\text { application of } \\
\text { climate-smart } \\
\text { initiatives } \\
\text { within these } \\
\text { practices }\end{array}$ & $\begin{array}{l}\text { Make campus } \\
\text { a green } \\
\text { campus } \\
\text { with climate } \\
\text { responsive } \\
\text { and environ- } \\
\text { mentally } \\
\text { friendly } \\
\text { practices } \\
\text { on campus } \\
\text { including } \\
\text { hostels and } \\
\text { gardens }\end{array}$ & $\begin{array}{l}\text { RWH\&C } \\
\text { techniques } \\
\text { Climate-smart } \\
\text { innovation } \\
\text { Online } \\
\text { management } \\
\text { review tool } \\
\text { Development } \\
\text { of a teaching } \\
\text { garden }\end{array}$ & $\begin{array}{l}\text { Green campus } \\
\text { initiative }\end{array}$ & $\begin{array}{l}\text { Teaching } \\
\text { gardens were } \\
\text { developed to } \\
\text { 'practise what } \\
\text { we preach'. } \\
\text { Rainwater } \\
\text { harvesting on } \\
\text { campus }\end{array}$ \\
\hline
\end{tabular}




\begin{tabular}{|c|c|c|c|c|c|c|}
\hline $\begin{array}{l}\text { Curriculum } \\
\text { and } \\
\text { learning } \\
\text { system } \\
\text { drivers } \\
\text { (Figure 1) }\end{array}$ & $\begin{array}{l}\text { Shift or } \\
\text { change in } \\
\text { driver }\end{array}$ & Contradiction & $\begin{array}{l}\text { Revised } \\
\text { outcome } \\
\text { (new } \\
\text { solution) }\end{array}$ & $\begin{array}{l}\text { Tools } \\
\text { developed } \\
\text { and used in } \\
\text { innovation } \\
\text { process }\end{array}$ & $\begin{array}{l}\text { Micro } \\
\text { processes of } \\
\text { innovations } \\
\text { by } \\
\text { individuals }\end{array}$ & $\begin{array}{l}\text { Macro } \\
\text { processes of } \\
\text { innovations } \\
\text { by the group, } \\
\text { network or } \\
\text { institution }\end{array}$ \\
\hline $\begin{array}{l}\text { Social- } \\
\text { political } \\
\text { drivers } \\
\text { Agricultural } \\
\text { drivers }\end{array}$ & $\begin{array}{l}\text { Need for more } \\
\text { practical } \\
\text { component in } \\
\text { curriculum }\end{array}$ & $\begin{array}{l}\text { Demands of } \\
\text { the academic } \\
\text { programme } \\
\text { versus } \\
\text { inclusion } \\
\text { of relevant } \\
\text { practical } \\
\text { components }\end{array}$ & $\begin{array}{l}\text { Focus more } \\
\text { on practical } \\
\text { components } \\
\text { and allow } \\
\text { students to be } \\
\text { more hands } \\
\text { on }\end{array}$ & $\begin{array}{l}\text { Using RWH\&C } \\
\text { techniques } \\
\text { in practical } \\
\text { classes } \\
\text { Referring } \\
\text { to teaching } \\
\text { garden }\end{array}$ & $\begin{array}{l}\text { RWH\&C } \\
\text { practical } \\
\text { projects } \\
\text { developed on } \\
\text { campus. } \\
\text { Student } \\
\text { project } \\
\text { planning a } \\
\text { garden using } \\
\text { RWH\&C } \\
\text { techniques }\end{array}$ & $\begin{array}{l}\text { Students are } \\
\text { involved in } \\
\text { the Amanzi for } \\
\text { Food project } \\
\text { on campus }\end{array}$ \\
\hline $\begin{array}{l}\text { Agriculture } \\
\text { and } \\
\text { educational } \\
\text { policy } \\
\text { drivers } \\
\text { Drivers } \\
\text { influenced } \\
\text { by climate } \\
\text { change }\end{array}$ & $\begin{array}{l}\text { System } \\
\text { required the } \\
\text { curriculum } \\
\text { and learning } \\
\text { practices } \\
\text { to support } \\
\text { adaptive } \\
\text { change to the } \\
\text { climate-smart } \\
\text { responsive } \\
\text { approach } \\
\text { with a solid } \\
\text { relevant object } \\
\text { and outcomes. }\end{array}$ & $\begin{array}{l}\text { Current } \\
\text { state of flux: } \\
\text { institutional } \\
\text { development } \\
\text { versus } \\
\text { institutional } \\
\text { innovation }\end{array}$ & $\begin{array}{l}\text { Policy shift } \\
\text { to include } \\
\text { climate } \\
\text { responsive } \\
\text { practices. } \\
\text { Integration of } \\
\text { climate-smart } \\
\text { responsive } \\
\text { topics into the } \\
\text { curriculum. }\end{array}$ & $\begin{array}{l}\text { Online } \\
\text { climate-smart } \\
\text { innovation } \\
\text { tool - } \\
\text { Management }\end{array}$ & $\begin{array}{l}\text { Integration of } \\
\text { climate-smart } \\
\text { responsive } \\
\text { topics into } \\
\text { curriculum }\end{array}$ & $\begin{array}{l}\text { Training } \\
\text { of staff in } \\
\text { climate- } \\
\text { responsive } \\
\text { agricultural } \\
\text { practices } \\
\text { Development } \\
\text { of a social } \\
\text { learning } \\
\text { network within } \\
\text { the Taung } \\
\text { irrigation area }\end{array}$ \\
\hline
\end{tabular}

The contradictions contribute to enabling the innovation process (see Table 1). However, the continued modelling of the activity system allowed the research participants to discuss the barriers hampering innovation. This initiated an analysis of the barriers to innovation within different levels of the curriculum and learning practices at provincial levels. Some of these barriers are discussed below.

\section{Challenges to and opportunities for innovation Policy and practice (Table 1, Section 1)}

The innovation pathway of the system was influenced by the policy shift within the Agricultural Education and Strategic plan in order to move from the almost exclusive focus on commercial agriculture to a more rural development and poverty eradication orientation (see Figure 1; DoA, 2005a, 2005b; AgriSETA, 2014; READ, 2015). At the provincial level, policies are in place. However, implementation of these policies at a sub-system level is not clear. Even though the research participants were initiated and actively engaged in the process of climate-smart innovation, the means for adequate alignment at policy level were unclear (see contradiction 1 in Table 1). The online climate-smart innovation tool, policy (van Staden, 2018) was developed during the innovation process to assist. 


\section{Innovation and development of learning networks within an institution in flux}

It was noted that the college activity system is undergoing both structural change (an anticipated change from agricultural college to agricultural training institute) and rule change (the policy shift to include climate-smart agriculture as a climate response) which affected the character and relevance of the object of the system. The system required the curriculum and learning practices to support adaptive change to the climate-smart responsive approach with a solid relevant object and outcomes. The proposed object of innovation stood in contrast with the existing ways of developing curriculum in an institutional context that was in continuous flux. The activity system had undergone various changes in the last five years. The entire national diploma programme changed in 2014. The North West Agricultural Strategic Plan introduced new strategies and policies that required implementation and adaptation in all sub-systems across the provincial Agricultural System. The head of campus has changed three times since 2013 (TAC, 2014b, p. 3) and the principal of the agricultural training institutes in the North West was replaced in 2017. Many staff changes occurred (six new lecturers joined the team in 2017) during the study.

The institutional changes have created a situation of flux so synergies and coordination are essential between the provincial imperative to innovate climate-smart approaches and the college-based imperative to adapt to a climate-smart curriculum. These changes in the management and academic staff made following the initial innovation plan developed by the research participants difficult, thus affecting the ability of the system to function and strive towards innovation. Innovation firstly occurred at a micro level. For example, through the development of the climate-smart review tool, the lecturers developed a better understanding of the value of climate responsive competencies and concepts. They were able to see the application of climate responsive concepts within their field of expertise. However, as the situation stabilised, more people became actively involved in the project, and as time passed, innovation occurred at a macro level with the development of a social learning network and online innovation mediating tools (see contradiction 5 in Table 1).

Taung Agricultural College was utilised as an agricultural learning site to establish a social learning network to ensure knowledge dissemination within the agricultural community. Social media groups were also established to assist and share knowledge between the college and other community members. The aim of establishing a learning network was to connect people and organisations within the Taung and Hartswater irrigation scheme to make climate responsive information more accessible to encourage the use of information in a collaborative way. The learning network supported the establishment and use of demonstration sites and activities within Taung Agricultural College.

\section{Knowledge and competencies of actors within the system}

Over the years, the needs within the curriculum have developed and changed. For the implementation of new knowledge and practice within the curriculum and learning practices, the educators within the system need to be trained in the new learning and teaching topics and practices (DoA, 2005a, 2005b; DAF, 2008, pp. 107-116). The academic staff do not always 
have access to or time for the new agricultural developments and research, as the colleges are not research institutes. Newly appointed staff do not necessarily have an academic background in agriculture nor practical experience, a finding also reported in the Eastern Cape, especially when it comes to new areas of study that have not previously been included in the agricultural college curricula, such as rainwater harvesting and conservation practices (Lotz-Sisitka et al., 2016, pp. 69-72) and climate change. To observe transformative agency processes in learning, agents need to be fully engaged in the action of learning (Archer, 1995). However, if the lecturers and curriculum developers do not have the necessary competencies, knowledge and tools, transformative agency to initiate innovation towards a climate-smart system is not possible or at best very difficult, as also reported in studies on sustainability in Higher Education by Togo (2009, pp. 128-143) and Agbedahin (2016, p. 178). In such a context, professional development programmes for academics become extremely important, but there are often too few, especially in new areas of study such as climate-smart agriculture. As time continued, research participants utilised the climate-smart innovation tools to review their own climate-smart responsiveness and this assisted in knowledge dissemination (van Staden, O’Donoghue, Lotz-Sisitka, 2018, pp. 4-9). A long ongoing knowledge and competency innovation process extended 2015 to 2019. This included 22 lecturers and students attending the Amanzi for Food Training of Trainers course focused on the access to and use of information on rainwater harvesting and conservation in a number of publications, and an introduction to climate-smart agriculture in October 2018. Three of these participants achieved Rhodes University NQF level 6 certificates and six participants achieved NQF level 5 certificates in May 2019. In 2018, rainwater harvesting and conservation practical projects became part of the student curriculum. In 2019, a teaching garden was established where rainwater harvesting and conservation methods were implemented by the students.

\section{Time and space configuration}

Lack of time was identified as one of the most central constraints in determining the curriculum innovation and integration of climate-smart responsive concepts. At the beginning of the study, lecturers indicated that they did not have time to incorporate the practical side of climate-smart agriculture such as rainwater harvesting and conservation practices into the curriculum. A key and repeated issue raised across this study was that there was not enough time for students to master the practical techniques and understand other practical aspects in an already overloaded timetable (see contradiction 4, Table 1). This is also reported in other agricultural education contexts (DAF, 2008; DAFF, 2010; Lotz-Sisitka et al., 2016; ASSAf, 2017). Time was also needed for micro innovations to lead to macro innovations (see Table 1).

\section{Discussion: Process of innovation}

Through interaction with the research participants during workshops, interviews and informal feedback discussions, it became clear that to integrate a climate-smart approach into the system is a challenging process. The implementation of innovative practices did not occur as quickly as expected due to a combination of structural and institutional historical and cultural 
factors, reflecting the complex process of agentive action described by Archer (1995). This study demonstrated why it takes time to change attitudes regarding the incorporation of climate-smart responsive components into the curriculum (see Table 1). It takes time to build relationships with communities and to participate in community projects. It takes time to incorporate the concepts and competencies into the curriculum and it takes time to train the trainers to incorporate the concepts into the curriculum (see Table 1).

Mukute's (2010) research showed that micro innovations are important 'steps' on the pathway to transformative agency and with continued support over longer periods of change, more complex forms of change can occur. The Eastern Cape Amanzi for Food case study began to show more substantive institution level impacts in terms of curriculum innovation and practice in the fourth year of its implementation, having started with the smaller steps found in this study's expansive learning process (Pesanayi, 2018).

Thus, expansive learning processes allowed the research participants within a system of institutional flux to analyse the system and model solutions. They allowed the research to focus on long-term change and micro innovations regarding knowledge engagement, network building and tool development instead of focussing on institutional change at a macro level (see Table 1). They allowed the workshop participants to focus on what they could change, how they could develop their own competencies and how to work around the continuous changes towards macro innovations. Through this, macro innovations occurred in the fourth and fifth year of the process (see Table 1 ).

The research indicated through the expansive learning cycles that catalysing the curriculum and learning system required specific tools, time, development of social learning networks and the understanding of the importance of micro-level innovation (see Table 1). Thus, in a fluid context, support of the innovation process should focus on developing tools and should provide sufficient time for developing and implementation of innovation plans at a microlevel as an important starting point for more macro-level changes that occur over longer time periods (Table 1 ).

\section{Conclusion}

Micro innovation was more likely to take place than institutional change within the curriculum and learning system and, as shown in this research, this process required substantive support and ongoing reflexive engagement. Thus, while people are part of society and ideologically framed concepts such as climate-smart agriculture within an agricultural innovation system are part of this reality, people also need to initiate their own individual innovations within the system to make sense of these wider concepts and benchmarks (Popkewitz, 2017). Archer (2007) suggested that structures cannot be reflexive per se, arguing that reflexivity is a property of humans not structures. Even though the curriculum review tool (climate-smart innovation tool) and the use of the practical component of rainwater harvesting and conservation supported the research participants during the curriculum innovation process, it was the gradual learning, reflexivity and emergent agency of the participants that led to the innovation beginning to happen or to be realised in practice. It is important to realise the power of the individual agent (Archer, 2007, 
p. 38) but it is also important to note Agbedahin's (2016, p. 178) finding that while innovations are linked to individual agents, innovation is less likely to be initiated and sustained without the necessary support from the institution and society. The development of a social learning network is essential to create a supportive system. The established social network strengthened the climate responsive learning and teaching practices within the system.

It is evident that to initiate institutional change, the agents need to be supported by management and other institutional structures in striving towards change. Through the analysis of the data, it has become clear that specialised support is required for any innovation processes within the curriculum and learning system during a time of institutional flux. This study showed that a climate-smart agriculture approach can be a functional response to climate change and can lead to engagement within the agricultural curriculum and learning system.

Catalysing innovation within the curriculum and learning system requires specific tools. These tools were, in this case, a curriculum review tool; climate responsive practical applications such as rainwater harvesting and conservation practices; time (the study started in 2015 and was ongoing in 2019); and, the understanding of the importance of micro-level innovation to initiate actual change at a macro level. Thus, even though the systems thinking approach provides a functional framework to support innovation, the agents (individuals) within the system also need to be recognised and supported for innovation to occur. The development of a social learning network is an important step towards innovation.

\section{Notes on the contributor}

\section{Van Staden, Wilma}

Rhodes University, South Africa

Wilma van Staden is a postdoctoral fellow at Rhodes University's Environmental Learning Research Centre. Her PhD thesis focused on climate-smart system innovations in agricultural colleges in South Africa. She is currently working on the Sustainability Starts with Teachers research programme funded by UNESCO.

\section{References}

Academy of Science of South Africa (ASSAf). (2017). Revitalising Agricultural Education and Training in South Africa. Consensus Study. Academy of Science of South Africa.

Aerni, P., Nichterlein K., Rudgard S., \& Sannino, A. (2015). Making Agricultural Innovation Systems (AIS) work for Development in Tropical Countries. Sustainability, 7(1), 831-850. doi: 10.3390/su7010831.

Agbedahin, A.V. (2016). A morphogenic and laminated system explanation of position-practice systems and professional development training in mainstreaming education for sustainable development in African Universities. Unpublished PhD thesis, Rhodes University, Grahamstown. 
AgriSETA. (2014). Agricultural Sector Skills Plan 2011-2016. September 2014. Update.

Archer, M. (1995). Realist Social Theory: The morphogenetic approach. Cambridge: Cambridge University Press.

Archer, M. (2007). The trajectory of the morphogenetic approach: An account in the firstperson. Sociologia. Problemas e Praticas, 54, 35-47.

Chakeredza S., Temu, A.B., Yaye, A., Mukingwa, S., \& Saka, J.D.K. 2009. Mainstreaming Climate Change into Agricultural Education: Challenges and Perspectives. ICRAF Working Paper no. 82. Nairobi, Kenya: World Agroforestry Centre.

Department of Agriculture (DoA). (2005a). AET Strategy - National Education and Training Strategy for Agriculture and Rural Development in South Africa.

Department of Agriculture (DoA). (2005b). Norms and Standards for Extension and Advisory Services in Agriculture Directorate: Scientific Research and Development, ed., Directorate: Agricultural Information Services. Retrieved June 1, 2016 from http://www.nda.agric. za/doaDev/sideMenu/NationalExtensionSupport/docs/NORMS_AND_STANDARD_ BOOKLET.pdf.

Department of Agriculture (DoA). (2008). National Agricultural Research and Development Strategy 2008. Retrieved June 1, 2016 from http://www.nda.agric.za/docs/Policy/ Research_and_Development_Strategy.pdf

Department of Agriculuture and Fisheries (DAF). 2008. Evaluation of agricultural education and training curricula in South Africa. Republic of South Africa.

Department of Agriculture, Forestry and Fisheries (DAFF). (2010). Agricultural Education and Training Access Barriers Report.

Engeström, Y. (1987). Learning by Expanding: An Activity-Theoretical Approach to Developmental Research. Helsinki: Orienta-Konsultit.

Engeström, Y. (1999). Innovative learning in work teams: Analysing cycles of knowledge creation in practice. In Y. Engeström, R. Miettinen \& R-L. Punamäki (Eds.), Perspectives on activity theory (pp. 377-406). Cambridge: Cambridge University Press.

Engeström, Y. (2016). Studies in Expansive Learning. Learning what is Not Yet There. Cambridge: Cambridge University Press.

Food and Agriculture Organisation (FAO). (2013). Climate-Smart Agriculture Sourcebook.

Lotz-Sisitka, H., Pesanayi, T., Weaver, K., Lupele, C., Sisitka, L., Denison, J. \& van Staden, W. (2016). Water use and food security: Knowledge dissemination and use in agricultural colleges and local learning networks for home food gardening and small scale agriculture. Volume 1: research and development report. Report to the Water Research Commission.

Mukute, M. (2010). Exploring and expanding learning processes in sustainable agriculture workplace contexts. Unpublished PhD thesis, Rhodes University, Grahamstown.

Pesanayi, T. (2018). Boundary crossing expansive learning across agricultural learning activity systems and networks in southern Africa. Unpublished PhD thesis, Rhodes University, Grahamstown.

Popkewitz, T. (2017). The promise of empirical evidence and benchmarks: The Lorelei's whispers. Research Gate. Retrieved January 28, 2018 from https://www.researchgate.net/ publication/32170927 
Potchefstroom College of Agriculture (PCA). (2009). Prospectus: Quality assurance, design development, delivery and evaluation of training programmes, assessment and off site. Potchefstroom: PCA.

Rural, Environment and Agricultural Development (READ). (2015). Annual Report for 2014/2015 Financial Year Vote 13. READ Province of the North West.

Sayer, A. (2000). Realism and Social Science. London: Sage.

Serage, D. (2015). May 26. Director of Structured Agricultural Training and Empowerment for the Department of Rural, Environmental and Agriculture Development for the North West province. Personal communication.

Spielman, D.J., Ekboir, J., \& Davis, K. (2009). The art and science of innovation systems inquiry: Applications to Sub-Saharan African agriculture. Technology in Society, 31, 399405.

Sumberg, J. (2005). Constraints to the adoption of agricultural innovations: Is it time for a re-think? Outlook on Agriculture, 34, 7-10. doi 10.5367/0000000053295141.

Taung Agricultural College (TAC). (2014a). Taung Agriculture College Prospectus.

Taung Agricultural College (TAC). (2014b). Amplified prospectus - Taung.

Togo, M. (2009). A systems approach to mainstreaming environment and sustainability in universities: The case of Rhodes University, South Africa. Unpublished PhD thesis, Rhodes University, Grahamstown.

Van Staden, W. (2018). Online Climate-Smart Innovation Tool for management. Available at: https://www.onlineassessmenttool.com/climate-smart-innovation-tool-management/ assessment-55035

Van Staden, W., Lotz-Sisitka, H. \& O’Donoghue, R. (2018). Climate-Smart Innovation Tool. A curriculum innovation support tool for the agricultural learning systems. Grahamstown, Rhodes University Environmental Learning Research Centre. Retrieved from http:// amanziforfood.co.za/csit-resources/

Vygotsky, L.S. (1978). Mind in Society. The development of higher psychological processes. Cambridge: Harvard University Press.

Yin, R.K. (2003). Case Study Research: Design and Methods (3rd ed.). London: Sage. 
